\title{
MAIN NUTRIENT PLASMA METABOLITE LEVELS IN PIGLETS FROM BIRTH THROUGH SIX WEEKS OF AGE AND IN FEEDER PIGS
}

\author{
M. DVORÁK \\ Veterinary Research Institute, 62132 Brno
}

Received November 21, 1978

\begin{abstract}
Dvořák M.: Main Nutrient Plasma Metabolite Levels in Piglets from Birth Through Six Weeks of Age and in Feeder Pigs. Acta vet. Brno, 47, 1978, 115-122.

Blood plasma glucose, total protein, cholesterol, free fatty acid (FFA) and urea concentrations were determined in 7 age categories of healthy piglets ranging from newborn to 42 days of age and comprising suckled and weaned animals and in feeder pigs having 30 to $98 \mathrm{~kg}$ in body mass. The first three of these parameters showed a marked rise in the first days of postnatal life, which coincided with the period of intense growih of body mass between the 2 nd and 19th days after birth. An early and continuous fall in total protein to below the level recorded in feeder pigs was no obstacle to growth. A fall in plasma cholesterol concentration, particularly pronounced after weaning, apparently reflects a lower intake of dietary fat. Similarly, plasma FFA concentration was lowest before ingestion of colostrum and after weaning, at which time it was lower than in feeder pigs. Plasma urea concentration changed little with age and growth rate during the suckling period, but rose considerably after weaning in response to post-weaning diet. Evaluation of the results separately for well-growing piglets and for those whose body mass was 39 to 47 per cent reduced without signs of emaciation from the 23rd day of age onwards showed little difference between the two groups in the levels of the metabolites under study.
\end{abstract}

Growth rate, total protein, glucose, cholesterol, free fatty acids, urea.

Biochemical examination of the organs, particularly blood plasma or serum, has become an integral part of the diagnosis of farm animal diseases. In the pig, however, little practical use has been made of the parameters of substance metabolism to date. An exception to this has been the determination of some vitamins, macroelements and, occasionally, microelements, the deficiency of which results in well-known pictures of clinical disorders. Much less information is available on the laboratory diagnosis of organ diseases (Wilson et al. 1972; Kraft 1975).

Determination of the normal values for biochemical parameters in the blood of piglets in particular has been the subject of numerous studies. Some of them were concerned with the physiology of the pig (Rybáčková and Holub 1966; Mašek and Holub 1970; Ježková et al. 1972), others were motivated by the use of pigs and miniature pigs in medical research (Bengtsson et al. 1969; Tumbleson and Kalish 1972; Carroll and Hamilton 1973; Tumbleson et al. 1976). Veterinary clinical research was directed mainly to the biochemical analysis of piglets' blood in relation to diarrhoea (Johnson and Tumbleson 1971; Svendsen et al. 1972; Martinsson et al. 1976) and neonatal pig hypoglycaemia (Swiatek et al. 1968; Dvořák 1975; Pohle and Gürtler 1976). Little attention, however, has been paid to the relations between the concentrations of various blood metabolites and body mass or gain in body mass, even though such indicators were considered as possible selection criteria in fattening pigs (Steger et al. 1976). Few data are also available concerning the metabolic state of stunted pigs (Dvořák 1963; Adamesteanu et al. 1974; Baba 1977).

Since unthriftiness of pigs may cause serious losses in large herds, checks on the substance metabolism of pigs seem worthy of consideration. However, it is not yet clear which parameters 
should be used in determining the metabolic profile and in which way the results should be interpreted. The present study was designed to follow the concentrations of glucose, total protein, urea, free fatty acids (FFA) and total cholesterol in the blood plasma of piglets from birth to 42 days of age, by which time the piglets were either still kept on the sow or were weaned at least one week previously. The results obtained from the 23rd day onwards were evaluated separately for well growing piglets and for piglets with lower body mass values, and comparison was made with the values recorded for feeder pigs. The aim was not only to provide an insight into the physiological changes occurring in piglets during their postnatal development, but also to evaluate possible relations of blood plasma concentrations of the major nutrient metabolites under study to growth rate expressed in terms of body mass and possibly to diet.

\section{Materials and Methods}

Clinically healthy Large White piglets from 15 litters reared in the Institute in all seasons of the year were employed. They had free access to water and were given a commercial prestarter (ČOS 1) from the beginning of the second week of postnatal life and a commercial starter (ČOS 2) after weaning. The only treatment which they received was preventive administration of Ferridextran (SPOFA). Two to five blood samples were withdrawn from the cranial vena cava of each piglet except those exsanguinated before ingestion of colostrum (day 0 ). The blood collections were made invariably between 7 and $8 \mathrm{a} . \mathrm{m}$. without previous food deprivation and the animals were weighed at the same time. They were classified into 7 age categories comprising animals aged 0,1 to 2,5 to 6,15 to 19,23 to 26,28 to 31 and 35 to 42 days. In the last three categories evaluation was made separately for well growing piglets and for piglets with reduced body mass without signs of emaciation, and in the last category separately in addition for suckled and weaned piglets. The numbers of animals involved are shown in Fig. 1. Altogether 241 blood plasma samples were obtained from piglets and 52 blood plasma samples from well growing feeder pigs having 30 to $98 \mathrm{~kg}$ in body mass.

The determination of FFA was carried out by the method of Duncombe (1964) as modified by Stajner and Sưva (1975). The concentrations of total protein and urea were determined using Biolatest (Lachema, Brno). Glucose was determined with the Fermognost test (VEB Arzneimittelwerk, Dresden). Total cholesterol was determined according to Pearson et al. (1953)
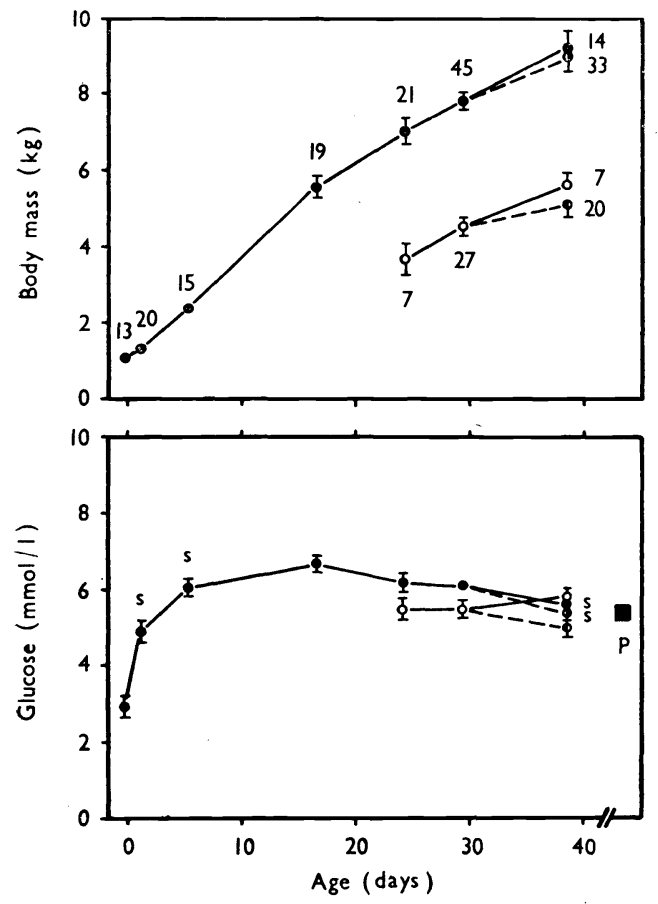
except that $p$-toluenesulphonic acid was replaced with sulphosalicylic acid. A mean and standard error of the mean (S. E. M.) was calculated for each parameter. The significance of the differences of the means was assessed by Student's $t$-test.

\section{Results}

The group of well growing piglets was characterized by their body mass which was doubled 4 to 5 days after birth and exceeded, on average, $9 \mathrm{~kg}$ at 35 to 42 days of age in both suckling and weaned piglets. Mean

Fig. 1.

Body mass and blood plasma glucose concentration in suckling piglets with good (closed circles) and reduced growth rate (open circles) and in the same piglets after weaning (semi-closed circles) as compared with the level found in feeder pigs $(P)$. The results are presented as means \pm S.E.M. The figures denote the numbers of animals examined and "s" denotes a significant difference from the preceding value. 


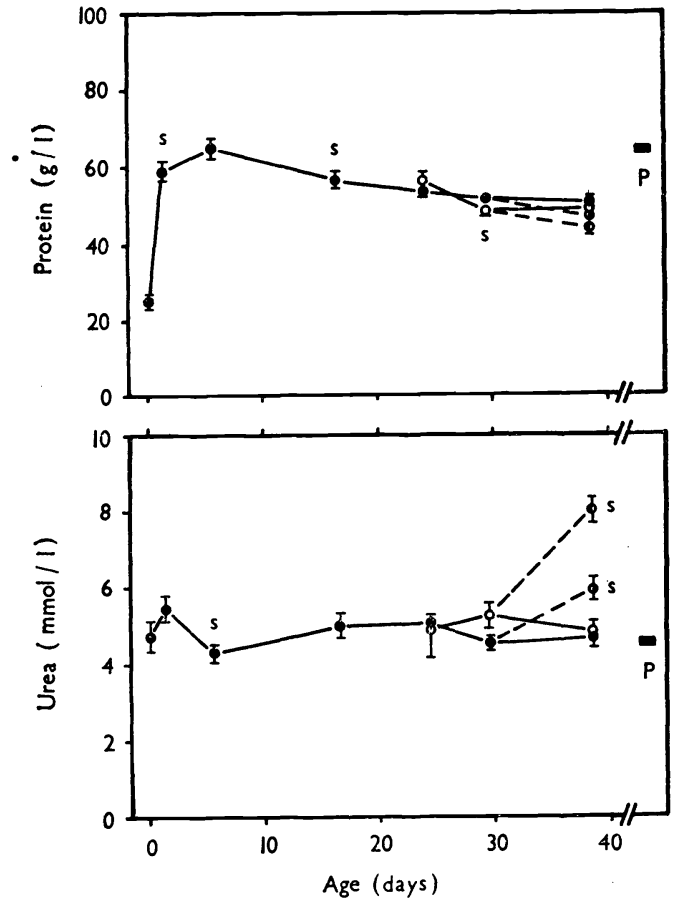

Fig. 2.

Total protein and urea concentration in the blood plasma of piglets and feeder pigs. For explanatory notes see Fig. 1.

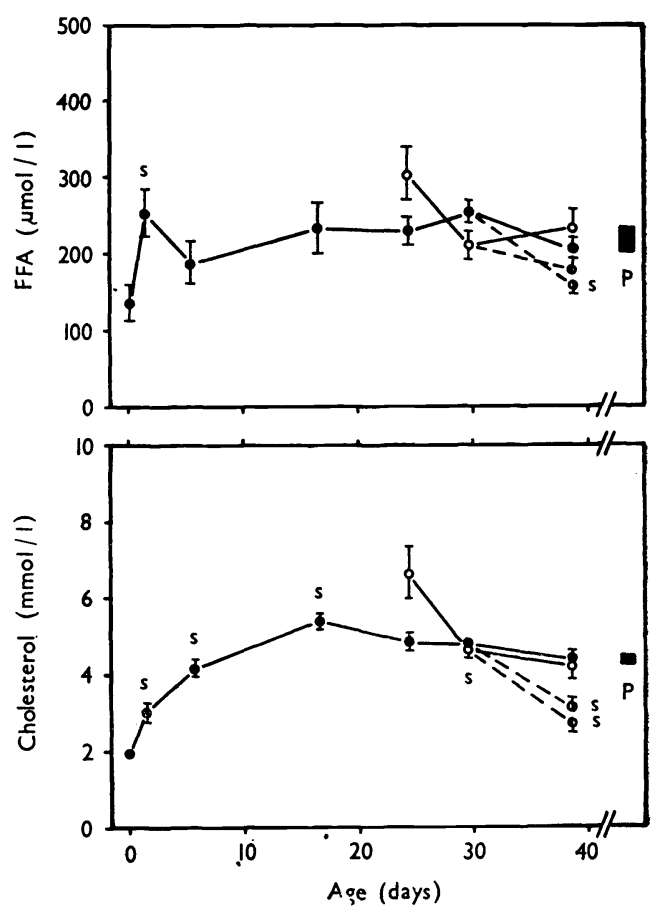

Fig. 3.

Free fatty acid (FFA) and cholesterol concentration in the blood plasma of piglets and feeder pigs. For explanatory notes see Fig. 1.

body mass of piglets referred to as animals with reduced growth rate was 39 to 47 per cent lower than that of their well growing counterparts, but no signs of emaciation or cachexia were present (Fig. 1).

Blood plasma glucose concentration was low before ingestion of colostrum, then rose up to 15 to 19 days, reaching a significantly $(P<0.05)$ higher level than in feeder pigs, and tended to decline in the 3rd week even in weaned piglets. The values found in piglets with reduced body mass were generally lower than those recorded for well growing animals, but did not differ significantly from the plasma glucose concentration of feeder pigs (Fig. 1).

Total protein concentration behaved similarly to the concentration of glucose in the first days after birth. It was significantly $(P<0.01)$ lower before ingestion of colostrum than at subsequent examinations or in feeder pigs. Afterwards it rose abruptly, reaching a peak corresponding to the value for feeder pigs as early as 5 to 6 days after birth. It became significantly $(P<0.01)$ lower in the $3 \mathrm{rd}$ week and continued to decline thereafter. There were no significant differences between the results obtained in piglets with good and reduced growth rate (Fig. 2).

Urea concentration changed little in suckling piglets, being generally higher, and at 1 to 2 and 23 to 26 days significantly $(P<0.05)$ higher, than in feeder pigs. After weaning it rose significantly $(P<0.01)$ both in well growing piglets and in animals with reduced body mass, though significantly $(P<0.01)$ more in the latter (Fig. 2). 
The FFA concentration in the blood plasma of well growing piglets was lowest before ingestion of colostrum and after weaning. It was only at these times that it differed significantly $(P<0.05)$ from the level found in feeder pigs and from the highest value recorded 1 to 2 days after birth. The concentration of FFA in piglets with reduced growth rate also varied and did not differ significantly from that found in well growing piglets, and the decrease after weaning was smaller (Fig. 3).

Total cholesterol concentration changed similarly to the concentration of glucose even in comparison with the level found in feeder pigs. The fall after weaning, however, was much sharper and significant $(P<0.01)$ as against the values found in equally old or 1 to 4 weeks younger suckling piglets and as against the cholesterol level of feeder pigs. There were no significant differences between the results obtained in piglets with good and reduced growth rate (Fig. 3).

\section{Discussion}

From the results reported here certain inferences can be drawn regarding the relation between the parameters of substance metabolism under study and body mass. The intense growth in body mass with mean daily gains of $277 \mathrm{~g}$ between 2 and 19 days of age was associated with rising and consistently high levels of glucose and cholesterol. Considering that foetal pigs were reported to gain only $116 \mathrm{~g}$ during the last ten days of intra-uterine life (Padaliková, 1970), these metabolites seem to be indicators of good growth. A close relationship of glycaemia to body mass during the last stage of intra-uterine development of foetal pigs has been demonstrated in previous work (Dvořák, 1975). The rise in FFA concentration in the first days after birth could also be regarded as a sign of increased gain in body mass, although further changes in the concentration of FFA did not show such an unequivocal tendency as glucose and cholesterol did. Urea level, on the other hand, was only little affected by breast feeding. According to Ježková et al. (1972) urea levels of foetal pigs varied considerably during the last 40 days of intra-uterine life, depending on the blood urea level of the dam. Therefore, urea concentration in the blood plasma of foetal does not give information on their synthesis of urea.

An interesting phenomenon during the aforementioned period of intense growth in body mass was the pattern of change in total protein. Its concentration increased 257 per cent during the first 5 to 6 days after birth. According to Tu mbleson and Kalish (1972) the proportion of total globulin and particularly of gamma globulin rises abruptly after ingestion of colostrum, whereas the proportion of albumin increases less steeply, and steadily, throughout the suckling period. In the 3rd week after birth the concentration of total protein was lower than in feeder pigs and continued to be so even in weaned piglets. This peculiar feature in the development of piglets, apparently due to inadequate synthesis of globulin fractions, is no obstacle to growth and, if within certain limits, cannot therefore be regarded as an indicator of reduced body mass. Adult total protein concentrations were reported for pigs aged 21 to 24 weeks (Swendsen et al. 1972); in miniature pigs the peak of total protein concentration was not found until the 19th month of age (Tumbles on et al. 1976).

A slowdown in the growth of body mass occurred after the 19th day of age. This is a well-known phenomenon which was analysed by Holub (1968) with reference to the functional periodization of postnatal development. It is at this 
time that relative lipid content of the piglet body ceases to rise after a previous, rather abrupt increase and that circulating blood plasma volume shows a decrease after a previous rise folowing ingestion of colostrum. Blood plasma cholesterol decreases particularly after weaning as demonstrated in previous studies (Dvoŕák 1967; Tumbles on and Kalish 1972). Low cholesterol levels were found in piglets exhibiting diarrhoea (Johnson and Tumbleson). According to Carrol and Hamilton (1973) plasma cholesterol levels in young animals are related to feed intake rather than to age. The deciding factor is presumably dietary fat. Addition of lard to starter for early weaned piglets tended to have a positive effect on cholesterol level and weight gain and produced a rise in blood glucose (Dvořák 1974).

Plasma glucose concentration, too, decreased after the 19th day of age, falling from a value higher than that found in feeder pigs to a level approaching this value. The pattern of change recorded here differed somewhat from that found on glucose determination in whole blood (Dvořák 1975), a fact apparently due to changes in erythrocyte glucose concentration (Rybáčková and Holub 1966). As in newborn pigs (Pohle and Gürtler 1976), conflicting data on glucose levels were recorded during the postnatal development. Thus, e. g., Bengtss on et al. (1964) found little change in glucose level between 3 days and 9 weeks after birth, whereas Tumbles on and Kalish (1972) found a decrease in the 3rd week followed by a steady rise till weaning.

FFA level, like plasma glucose level, is regarded as one of few measures of the peripheral metabolic state in the control of energy stores (Bray and Campfield 1975). The data currently available on their concentration in piglet plasma are meagre. The findings in the present study of a low plasma FFA level immediately after birth and its subsequent rise are in keeping with the results reported by Bengtsson et al. (1965) and Brenner and Gürtler (1976). Considering that fasted newborn piglets were reported to show only a slight and temporary rise in FFA concentration ( $\mathrm{S}$ wiatek et al. 1968), it seems reasonable to regard exogenous triglycerides as the main source of circulating FFA in suckling piglets at least during the time that the relative fat content in the body is low. The marked decrease in FFA concentration after weaning signalled the change in diet and, considering its similarity to the cholesterol level, was presumably also due to reduced supply of exogenous fat. In fact, a similar decrease was found in rats changed from a high fat diet to a carbohydrate one (Zaragoza and Felber 1970). However, the possibility cannot be excluded that FFA were utilized at a higher rate in consequence of the metabolic situation associated with weaning.

Plasma urea concentration, which showed no relation to body mass and little, if any, relation to body mass gain in suckling piglets, increased considerably after weaning in well-growing piglets as well as in animals with reduced body mass. This metabolite, or possibly urea nitrogen, is regarded as a reliable indicator of protein intake as to both protein amount and biological value also in the pig (Garner et al. 1957; Münchow and Bergner 1967). The increased urea level in the blood plasma of piglets after their change from breast feeding to postweaning diet of lower value cannot be a manifestation of increased protein intake, but may indicate its lower biological value or possibly a higher rate of protein catabolism. An increase in urea concentration after weaning was reported also by Tumbleson and Kalish (1972) and Adamesteanu et al. (1974). In their studies, however, the post-weaning urea concentration did not exceed the values recorded for suckling pigs; extremely high values were found in stunters. 
The results obtained in piglets with reduced body mass did not provide conclusive evidence as to the relation of any of the parameters of substance metabolism under study to this state, although a relation of glucose concentration to thriftiness was suggested. A similar observation was also made in calves (Little et al. 1977). The evidence from another study suggests that, besides red blood picture, total protein level is a convenient measure of health status in calves (Staples et al. 1961). The same might be true of the piglet with respect to its immune status. A decrease in total protein concentration was found in diarrhoeic piglets (Martins s on et al. 1976). In healthy piglets, however, no conclusive evidence has been obtained so far to indicate the usefulness of total protein level as indicator of growth rate expressed in terms of body mass, even though both total protein concentration and growth were reduced in protein-restricted pigs (Grimble and Whitehead 1969).

The results reported here confirmed that all the indicators under study are related to age and are useful in studies on the effects upon substance metabolism. However, their diagnostic usefulness as indicators of pig thriftiness in the field is open to question. Determination of urea concentration and, possibly, cholesterol concentration might be useful in assessing the quality of ingested feed. FFA should receive more attention in future as a major lipoprotein component of the blood, although the diagnostic value of FFA level may be reduced by its considerable variability. All the parameters under study changed more or less after weaning. The relation of the metabolites to body mass gain during the post-weaning period will be the subject of another study.

\section{Hladiny plasmatických metabolitů hlavních živin $\mathrm{v}$ průběhu vývoje selat a u běhounư}

U 7 věkových kategorii zdravých selat od narozeni do stáři 42 dní, sajících i odstavených a u běhounů $\mathrm{s}$ hmotností $30-98 \mathrm{~kg}$, byla stanovena v krevní plasmě koncentrace glukózy, celkového proteinu, cholesterolu, neesterifikovaných mastných kyselin (NEMK) a močoviny. V první dny postnatálního života byl zaznamenán výrazný vzestup u 3 prvně uvedených parametrů. $S$ jejich vysokými hladinami bylo spojeno údobí nejintenzívnějšího narưstání tělesné hmotnosti od 2. do 19. dne života. Casný a trvající pokles u proteinu pod úroveň hladin vyskytujících se $u$ běhounů nebyl překážkou dobrému růstu. Pokles koncentrace cholesterolu, výrazný zvláště po odstavu, naznačuje spojení s nižším přívodem tuku v potravě. Podobně koncentrace NEMK byla nejnižší u selat před napitím kolostra a po odstavu, kdy se též lišila od hladiny zjištěné u běhounư. Malé změny koncentrace plasmatické močoviny nejevily během údobí sání zřetelný vztah ke stáŕi ani $\mathrm{k}$ tělesné hmotnosti. Avšak její velké zvýšení po odstavu prokazuje vztah $k$ přijímanému krmivu. Selata, jejichž tělesná hmotnost po 23. dni života byla bez příznaků vyhublosti redukována v průměrech o 39 až $47 \%$, ukazovala ve srovnání s dobře rostoucími relativně malé odchylky v hladinách sledovaných metabolitů.

\section{Уровни плазматических метаболитов основных питательных веществ в прсцессе развития поросят и подсвинок}

У 7 возрастных категорий здоровых поросят со дня рождения до возраста 42 дней, молочных и отъемных, и у подсвинок весом 30-98 кг, определялась в кровяной плазме концентрация глюкозы, общего протеина, холестерина, не 
этерифицированных жирных кислот (НЭЖК) и мочевины. В первые дни после рождения отмечалось выразительное повышение приведенных первых трех параметров. С их высокими уровнями был связан период самого интенсивного увеличения массы тела от 2 до 19 дней жизни. Раннее и все продолжающееся понижение в случае протеина под уровни, имеющие место у подсвинок не препатствовало хорошему росту. Понижение концентрации холестерина, особенно яркое после отъема, дает возможность судить о более ограниченном приеме жиров в пище. Подобным образом концентрация НЭЖК была самой низкой у поросят перед потреблением молозива и после отъема, когда она также отличалась от уровня, установленного в случае подсвинок. Небольшие изменения концентрации плазматической мочевины не свидетельствовали в течение периода подсоса о явном отношении к возрасту ни массе тела. Однако, ее резкое увеличение после отьема свидетельствует о5 отношении к принимаемым кормам. Поросята, масса тела которых спустя 23 дня жизни не отличалась признаками похудения, однако, достигала понижения в среднем на $39-47 \%$, отличалися, по сравнению с хорошо растущими, небольшими отклонениями уровней наблюдаемых метаболитов.

\section{References}

ADAMESTEANU, I. - ADAMESTEANU, C. - DANIELESCU, N. - ROTARU, O. MOLDOVAN, N. A.: Entwicklung des Glukose- und Harnstoffgehalts im Blut mit zunehmendem Alter bei normalen Ferkeln und Kümmerern in der Intensivschweinezucht. Dte. Tierärztl. Wschr., 81, 1974: 406-409.

BABA, Al. I.: Hypotrepsie des porcelets. Zbl. Vet. Med. A 24, 1977: 57-62.

BENGTSSON, G. - GENTZ, J. - HAKKARAINEN, J. - HELLSTRÖM, R. - PERSSON, B.: Plasma level of FFA, glycerol, $\beta$-hydrobutyrate and blood glucose during the postnatal development of the pig. J. Nutr., 97, 1969: 311-315.

BRAY, G. A. - CAMPFIELD, L. A.: Metabolic factors in the control of energy stores. Metabolism, 24, 1975: 99-117.

BRENNER, K. V. - GÜRTLER, H.: Die Kortisolkonzentration im Blutplasma beim neugeborenen Ferkel und nach ACTH-Belastung. Endokrinologie, 67, 1976: 198-203.

CARROL, K. K. - HAMILTON, R. M. G.: Plasma cholesterol levels in suckling and weaned calves, lambs, pigs and colts. Lipids, 8, 1973: 635-640.

DUNCOMBE, W. G.: The colorimetric micro-determination of nonesterified fatty acids in plasma. Clin. chim. Acta, 9, 1964: 122-125.

DVOŘ́K, M.: Siderémie a kapacita krevního séra vázat železo u selat se zpožděným růstem. Věd. Práce VÚVL Brno, 3, 1963: 63-71.

DVOŘ́K, M.: Hladiny celkového cholesterolu u selat ve vztahu ke stáŕí a $\mathrm{k}$ adrenokortikální aktivitě. Vet. Med., Praha, 12, 1967: 61-67.

DVOŘ́K, M.: Effects of dietary fat on growth rate and responsiveness to stress in weaned piglets. Acta vet., Brno, 43, 1974: 327-333.

DVOŘ́K, M.: Glycaemia in foetal, suckling and weanling pigs in relation to body weight. Docum. vet., Brno, 8, 1975: 127-137.

GARNER, R. J. -- CRAWLEY, W. - GODDARD, P. J.: Blood changes in piglets associated with weaning. J. comp. Path., 67, 1957: 354-357.

GRIMBLE, R. F. - WHITEHEAD, R. G.: The relationship between an elevated serum amino acid ratio and the development of other biological abnormalities in the experimentally malnourished pig. Br. J. Nutr., 23, 1969: $791-804$.

HOLUB, A.: Funkční periodisace časného postnatálního údobí u selat. Acta Univ. Agric, Fac. vet., Autoreferáty, Brno, 1968, 125 p.

JEŽKOVÁ, D. - HOLUB, A. - SMRČKOVÁ, M. - PADALÍKOVÁ, D.: Liver ornithine carbamyl transferase and blood plasma urea of pregnant sows and their foetuses in the last third of gestation. Acta vet. Brno, 41, 1972: 241-249.

JOHNSON, J. L. - TUMBLESON, M. E.: Serum biochemic values in piglets exhibiting diarrhea. Southwest. Vet., 25, 1971: 297-298. 
KRAFT, W.: Verhalten einiger klinischer, Blut- und Serumparameter bei Schwein mit akuter Herz- und Kreislaufinsuffizienz. Zbl. VetMed., A 22, 1975: 808-818.

LITTLE, W. - KAY, R. M. - MANSTON, R. - ROWLANDS, G. J. - STARK, A. J.: The effects of age, live-weight and feed intake on the blood composition of young calves. J. agric. Sci., Camb., 89, 1977: 291-286.

MARTINSSON, K. - EKMAN, L. - JÖNSSON, L.: Hematological and biochemical analyses of blood and serum in pigs with regional ileitis with special reference to the pathogenesis. Acta vet. scand., 17, 1976: 233-243.

MASEKK, J. - HOLUB, A.: Blood serum protein components in newborn piglest of different birth weights. Acta vet. Brno, 30, 1970: 391-395.

MÚNCHOW, H. - BERGNER, H.: Untersuchungen zur Proteinbewertung von Futtermitteln. 2. Die Harnstoffkonzentration im Blut von Ratte and Schwein in Abhängigkeit vom biologischen Wert des gefütterten Nahrungsproteins. Arch. Tierernähr., 17, 141-150.

PADALÍKOVÁ, D.: Váha fetů selat v posledním trimestru intrauterinního života. Čs. Fyziol., 19, 1970: 176.

PEARSON, S. - STERN, S. - McGAVACK, T. H.: A rapid accurate method for the determination of total cholesterol in serum. Analyt. Chem., 25, 1953: 813-814.

POHLE, R. - GÜRTLER, H.: Altersanhängige Veränderungen der Konzentration von Glukose und Fruktose im Schweineblut. Mh. VetMed., 31, 1976: 900-905.

RYBÁČKOVÁ, J. - HOLUB, A.: Glucosemia and erythrocyte glucose utilization in piglets of various ages reared on semisynthetic highcaloric diet. Sbornik VŠZ Brno, Spisy Fak. vet., 14, 1966: 569-575.

STAJNER, A. - SƯVA, J.: Příspěvek ke stanoveni neesterifikovaných mastných kyselin v krevním séru. Čs. Fyziol., 24, 1975: 247.

STAPLES, G. E. - ADREWS, M. F. - PARSONS, R. M. - McILWAIN, P.: Relationship of some blood components to morbidity and mortality in auction calves. Cornell Vet., 59, 1969: $313-325$.

STEGER, H. - OTTO, E. - ROMMEL, P. - PÜSCHEL, F.: Biochemische Kennwerte als Selektionsmerkmal 2. Untersuchungen an MPA-Schweinen. Arch. Tierzucht, 5, 1976: $321-339$.

SVENDSEN, J. - WILSON, M. R. - EWERT, E.: Serum protein levels in pigs from birth to maturity and in young pigs with and without enteric colibacillosis. Acta vet. scand., 13, 1972: 528-538.

SWIATEK, K. R. - KIPNIS, D. M. - MASON, G. - CHAO, K. L. - CORNBLATH, M.: Starvation hypoglycemia in newborn pigs. Am. J. Physiol., 214, 1968: 400-405.

TUMBLESON, M. E. - KALISH, P. R.: Serum biochemical and hematological parameters in crossbred swine from birth through eight weeks of age. Can. J. comp. Med., 36, 1972:202-209.

TUMBLESON, M. E. - HUTCHESON, D. P. - MIDDLETON, C. C.: Serum protein concentrations and enzyme activities as functions of age and sex, in Sinclair (S-1) miniature swine. Growth, 40, 1976: 53-68.

WILSON, G. D. A. - HARVEY, D. G. - SNOOK, C. R.: A review of factors affecting blood biochemistry in the pig. Br. vet. J., 128, 1972: 596-610.

ZARAGOZA, N. - FELBER, J. P.: Studies on the metabolic effects induced in the rat by a high fat diet. Horm. metab. Res., 2, 1970: 323-329. 